\title{
Corrigendum: Rapid increases in tropospheric ozone production and export from China
}

Willem W. Verstraeten, Jessica L. Neu, Jason E. Williams, Kevin W. Bowman, John R. Worden and K. Folkert Boersma

Nature Geoscience 8, 690-695 (2015); published online 10 August 2015; corrected after print 23 June 2016.

In the version of the Letter originally published, in the last sentence of the Fig. 1 caption, the coordinates given for the dashed boxes in Fig. 1 and Fig. 3 were incorrect. The coordinates for eastern China should have been ' $108^{\circ}-123^{\circ} \mathrm{E}, 20^{\circ}-44^{\circ} \mathrm{N}^{\prime}$ and not ' $105^{\circ}-129^{\circ} \mathrm{E}$, $18^{\circ}-42^{\circ} \mathrm{N}$ ', and the coordinates for western US should have been ' $130^{\circ}-105^{\circ} \mathrm{W}, 30^{\circ}-50^{\circ} \mathrm{N}$ ' and not ' $130^{\circ}-105^{\circ} \mathrm{W}, 20^{\circ}-50^{\circ} \mathrm{N}$. This has been corrected in the online versions of the Letter. 